\title{
Corporate Social Responsibility and Mobile Telecommunication Competitiveness in Nigeria: The Case of MTN Nigeria
}

\author{
John Efiok Nsikan*, Victor A. Umoh, Mbaa Bariate \\ Department of Business Management, University of Uyo, Uyo, Nigeria \\ Email: ${ }^{*}$ nsikiboy5000@yahoo.com
}

Received 4 July 2015; accepted 9 August 2015; published 12 August 2015

Copyright @ 2015 by authors and Scientific Research Publishing Inc.

This work is licensed under the Creative Commons Attribution International License (CC BY). http://creativecommons.org/licenses/by/4.0/

(c) (i) Open Access

\section{Abstract}

In Nigeria, the aftermath of the Niger Delta crises had spark off research interest on corporate social responsibility (CSR) and environmental sustainability. However, how telecommunication firms in Nigeria perceive and practice CSR and the link with competitive advantage is rarely investigated. This study examines the extent of relationship between CSR and mobile telecommunication competitive advantage. The survey design was adopted, making use of random sampling to select 200 participants from staff of MTN. Structured questionnaire was employed to collect relevant primary data and analysis was carried out through regression analysis and Chi-square technique. Results showed that except staff welfare, significant relationship existed between environmental awareness, community wellbeing and competitive advantage. To further enhance competitiveness, the firm's social responsibility to its workforce should be improved upon by introducing flexible working hours, facilitating work/life balance, ensuring prompt promotion, and considering internal advancement as a strategic option.

\section{Keywords}

Corporate Social Responsibility, Staff Welfare, Environmental Awareness, Community Wellbeing

\section{Introduction}

The mobile telecoms industry in Nigeria is currently going through intense competition as several communication companies (MTN, Globacom, Airtel and Etisalat, Visa phone, Multtichoice, Starcomms among others)

\footnotetext{
*Corresponding author.
}

How to cite this paper: Nsikan, J.E., Umoh, V.A. and Bariate, M. (2015) Corporate Social Responsibility and Mobile Telecommunication Competitiveness in Nigeria: The Case of MTN Nigeria. American Journal of Industrial and Business Management, 5, 527-537. http://dx.doi.org/10.4236/ajibm.2015.58052 
jockey for fair share of market space. Consequently, it would not be out of place for communication firms to device strategies and programs capable not only to contend the forces of competition, but also to achieve and sustain competitive advantage. Beside the well known generic strategies dominating the literature, telecoms companies globally are currently considering socially responsible behaviours as a viable strategy with a view to winning and sustaining customers’ patronage.

In this regard, more and more organisations are beginning to see the competitive benefits from setting up strategic CSR agendas, as the CSR movement spread the world over. Indeed, the concept of CSR and its variants (public accountability, corporate governance, corporate citizenship and corporate sustainability) has even found inroad application lately into the public sector [1] and in recent years, a large number of methods and application frameworks have been developed.

The widespread research interest and continuous academic discussions on CSR have perhaps been sustained in response to the challenges posed by globalization, environmental awareness and sustainability issues, intense market competition and its sociological implications, and the ever increasing growth in communication and information technology [2] [3]. These challenges have enormous implication to corporate business managers as well as stakeholder communities.

CSR is a way companies manage their businesses with a view to making positive and healthy impact on the society, through their economic, environmental and social activities. It is a business strategy meant to assist firms strike a balance between the need to achieve economic and financial objectives and the socio-environmental impact of their activities [4] [5]. A careful assessment of social responsibility and sustainability literature [4] [6]-[9] seems to point to one conclusive reality that beyond profit maximization, (assumed to be the main object of corporate entity) the success, survival and sustained competitiveness of corporations depend upon their involvement in actions meant to improve the welfare of the reference community.

In Nigeria, interest and research on CSR have recently been upbeat following the aftermath of the Niger Delta crises involving multinational oil firms. Most of these studies have focused on multinational companies. They have ignored indigenous companies and the context in which they operate [4]. Similarly, studies investigating how telecommunication industry in Nigeria perceives and practices CSR and the link with competitive advantage are relatively under-researched. This study examines corporate social responsibility and its implications for market competitiveness. It investigates whether a firm's concern about improved staff working conditions, improved working environment and community wellbeing enhances its competitive advantage. Consequently, we asked the following research questions:

1) Does the MTN's concern towards improving staff working conditions impact on its level of competitiveness?

2) How does the company's concern towards the working environment affect its competitive advantage?

3) To what extent does the company's contribution towards community wellbeing enhance its competitive advantage?

\section{Theoretical Framework}

This study adopts the Achie Carroll's CSR Pyramid theory. One of the most used and quoted models of CSR is Carroll's 1991 Pyramid of Corporate Social Responsibility [10]. Carroll considers CSR to consist of four social responsibilities; economic, legal, ethical and philanthropic, with decreasing importance in that order. Carroll's pyramid illustrates these four kinds of social responsibilities as shown in Figure 1.

For the past two decades Carroll's Pyramid of Corporate Social Responsibility has been used widely by both business managers and academics to better define and explore CSR [8]. The Pyramid has been useful to managers in particular to see the different obligations that the society within which they operate expect from businesses. Carroll has integrated the concepts of stakeholders and corporate citizenship into the pyramid. The economic component which is at the base of the pyramid gives top priority to economic performance serving as the foundation of the other components of the pyramid. The thinking and position here is that a business has to be profitable, plan for the future and provide shareholders with sufficient and attractive returns.

The legal component which is the second on the hierarchy expects businesses to comply with the laws and regulations of the society whilst pursuing profit within the framework of the law. The third hierarchy in Carroll's pyramid is the ethical responsibilities which are about how society expects businesses to embrace values and norms even if the values and norms might constitute a higher standard of performance than required by law 


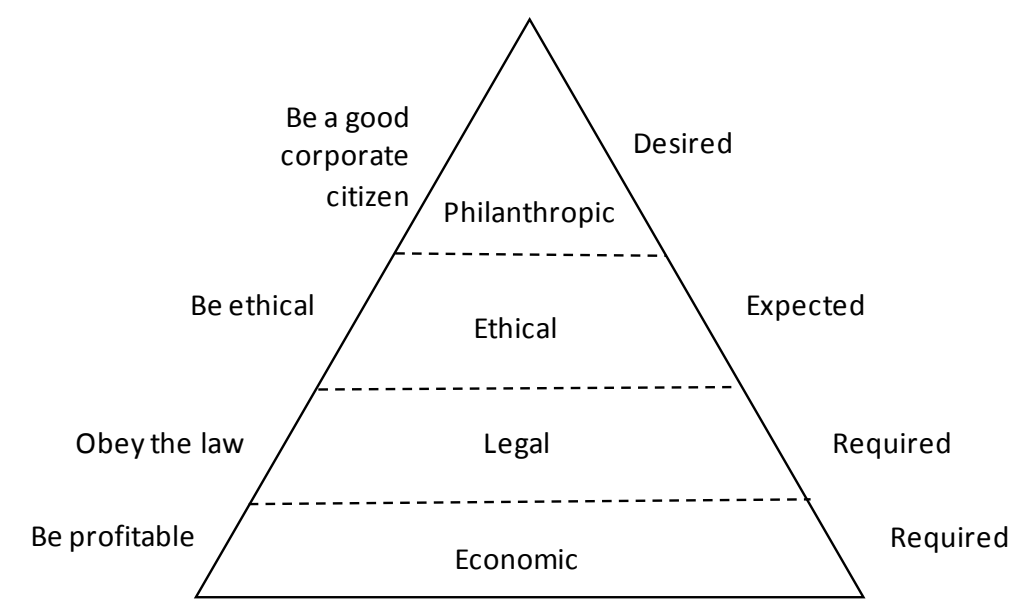

Figure 1. Pyramid of CSR. Source: Grant (2009) in Caroll’s (1991) Pyramid of CSR.

[11]. Furthermore, it involves avoiding questionable practices. However, ethical responsibilities are more difficult to deal with as they tend to be ill-defined and continually under public debate.

At the top of the pyramid is philanthropic responsibility. The philanthropic responsibilities are those actions that society expects from a business to be a good corporate citizen [5]. It involves giving back to the community and being a good corporate citizen through donations and active participation in charities or other community welfare programs [12]. The application of Carroll's theory is important in the context of this study for its robustness in classifying CSR expectations and obligations into the four relevant domains; thus providing the study with a focus in which to streamline its investigation. Secondly, the wider acceptability and application of Carroll's CSR model in strategic management and social issues in management researchers and practitioners also make it suitable for application in this current research.

\subsection{Corporate Social Responsibility}

As pointed out by [13], CSR is a difficult concept to define accurately. It overlaps with other such concepts as corporate citizenship, sustainable business, environmental responsibility, the triple bottom line, social and environmental accountability, business ethics and corporate accountability. It is highly contextual not only in terms of its corporate environment but also in terms of its national environment. However, there are some notable definitions considered in this study.

For example, the Australian Treasury, in a submission to the Joint Parliamentary Inquiry on CSR, defined CSR as "a company's management of the economic, social and environmental impacts of its activities" [14]. Similarly, the Neo-Keynesians tend to utilize a wider definition that more clearly recognizes the active role of the corporation's "stakeholders", and perhaps also the state in the definition of corporate social responsibility. To the Keynesians, CSR is generally defined as an approach adopted voluntarily by corporations and without external regulation by either stakeholders or the state. For example, the European Union's (EU) in 2001 described corporate social responsibility as "a concept whereby companies integrate social and environmental concerns in their business operations and in their interaction with their stakeholders on a voluntary basis".

[15] emphasize that CSR is a permanent pattern of business activities aimed at fulfilling and exceeding legal and governmental expectations, ensuring employee safety and health as well as improving the well-being of the local community. [16] describes CSR as "a company's commitment to operating in an economically, socially, and environmentally sustainable manner, while recognising the interests of its stakeholders, including investors, customers, employees, business partners, local communities, the environment, and society at large”. In line with European Union's definition, CSR in this study is viewed as corporate ethical conduct, implying that a corporation is responsible for the general stakeholders, and not just stockholders. CSR is rooted in the recognition that businesses are an integral part of society and as such they have the potential to make a positive contribution to social goals and aspirations. CSR is argued to play some positive role in profit-making, it is also seen as an important insurance strategy to minimise risks from negative government intervention, adverse media coverage and consumer or stockholder backlash to corporate behaviour. 


\subsection{Defining Competitive Advantage of a Firm}

The concept of competitive advantage can be applied at different levels, from the firm (micro) level, to the regional and national (macro) level. Competitiveness at macro-economic level is defined as a sustained rise in the standards of living. Sector-level competitiveness refers to the performance of a given industry in a given country or region relative to the same industry in other countries or regions. A sector could be characterized as competitive on the basis of its capacity to grow, to innovate and to produce more and higher-quality goods and services, and to keep or gain market shares in international and domestic markets. A frequently cited definition of competitiveness at the firm level is provided by the US President's Commission on Industrial Competitiveness: "A firm is competitive if it can produce products or services of superior quality or lower costs than its domestic and international competitors".

Accordingly, competitiveness is then synonymous with a firm's long-run profit performance and its ability to compensate its employees and provide superior returns to its owners. In the narrow sense, measures of competitiveness at the firm level therefore comprise indicators of financial performance, such as the development of sales, profits, and costs, as well as stock performance.

According to [6], Hofer and Schendel introduced the concept of firm level competitive advantage to the field of strategic management in 1978. They explained that competitive advantage is obtained by companies through allocation of resources and development of a unique resource positioning distinct from other competitors. [2] points out in his book "Competitive Advantage" that competitive advantage comes from the values business creates for customers, and he defines competitive advantage as having a long-term, unique and advantageous competitive position relative to other competitors. He argues that competition is the key to success and determines all the activities related to the company's overall performance, such as; innovation, cultural cohesion and the efficiency of implementation; while advantage means company can gain ascendancy in any environment [2]. Moreover, a company can use three strategies to provide value for the purchase: cost leadership, differentiation and focus strategies (ibid).

[17] believe, "When a firm earns a higher rate of economic profit than the average rate of economic profit of other firms competing within the same market, the firm has a competitive advantage in that market." [18] posit that if the high economic profits can be maintained for several years, it could suggest that the firm has a sustainable competitive advantage. [5] claimed that the assets and skills are the basis for a company since they provided a sustained competitive advantage and long-term performance. [11] define the competitive advantages as the qualities possessed by the company in product or market scope, and these qualities can bring the company to a better position. From the summary above, it can be seen that though there is no unique definition of competitive advantage, all different interpretations of competitive advantage stress that competitive advantage is used relative to competition.

\section{Materials and Methods}

The study employed descriptive survey approach based on its economy, rapid data collection and ability to understand the characteristics of the population under study [19]. The design also has an advantage of producing good amount of responses from a wide range of population. The target population was all the staff of MTN Nigeria whose corporate headquarters situate along Akin Adesola Street, Victoria Island in Lagos. Accessible record shows that total population size of employees at the time of this study was 1326 . This population size; the record showed, was made up of 980 junior level staff, 327 middle level managers and supervisors, and 19 top management staff.

Taking a census of the entire population was not feasible, probability and non-probability sampling techniques were then used. Firstly, purposive sampling was used to select respondents from the operations units, customer care service, public relations, and corporate services units of MTN Nigeria because, by the nature of their job function, workers in these units were considered to have requisite information on the issues discussed in the study. Then, simple random sampling technique was employed to select 200 respondents from the above groups and 200 copies of questionnaire were administered accordingly. Collection of relevant primary data for the study was possible through structured questionnaire which was drawn from the research questions. There were 15 questions in all; each having five close-ended scales. CSR was taken as the explanatory variable while corporate competitiveness was the response or criterion variable. Consistent with [5], CSR was measured by three constructs: concern for staff welfare, concern for operational environment, and concern for community 
wellbeing. On the other hand, customer satisfaction, operational cost reduction, and profitability were measures of competitiveness in the study.

Descriptive presentation tools such as tables, frequency counts, and percentages were used to present research results. Data was analysed through multiple regression and Chi-square analysis. Regression was carried out to ascertain direction of relationship between dependent and independent variables and to determine the contributions of each predictor (independent) variable towards forecasting changes in the criterion (dependent) variable. It was necessary to employ a non-parametric test statistics (the Chi-square) to determine the contribution effect of community awareness on competitive advantage of the study organization. The collected data were coded and entered using the Statistical Packages for Social Science (SPSS), version 20.

\section{Research Result and Findings}

\subsection{Socio-Demographic Characteristics of Sample Respondents}

As earlier stated, 200 copies of the questionnaire were administered, but 142 returned copies were properly filled and usable for the study. Data on Table 1 shows the results socio-demographic distribution of respondents. As indicated, $54.2 \%$ of participants were male and $45.8 \%$ were female. Thus, it can be deduced from the result that the views being expressed in the study are representative of both male and female respondents with male respondents in majority. Among the respondents, $45.8 \%$ were single and $54.2 \%$ were married. This implies that the study has more married respondents than single respondents.

On the basis of educational qualification, respondents consist of 2.1\% SSCE/WASC certificate holders, 5.6\% OND/NCE diploma certificate holders, 75.4\% HND/B.Sc./B.A graduates, and 16.9\% master's degree holders. This simply suggests that most respondents were well educated to understand the issues at stake and to contribute accordingly.

The table also shows that $29.6 \%$ were below 30 years, $57.7 \%$ were between 30 - 40 years, $9.2 \%$ were between 41 - 50 years, and $3.5 \%$ were above the age of 50 years. Thus, majority of respondents were between $30-40$ years old. This dominant age grade is plausible for this study as it is perceived that most respondents are matured enough to have witnessed the socially-related activities of the telecoms firms operating in their community, and would be in a position to make meaningful contributions accordingly to the study.

In addition, results also reveal that $53.3 \%$ of respondents have less than 5 years of working experience, $31.9 \%$ of respondents have worked between 6 - 10 years, 5.2\% of respondents have 11 - 15 years experience, and 9.6\% have 16 years and above job experience with their company. From this result, it can be inferred that greater majority of respondents have over five years. Thus, respondents are likely to be knowledgeable on the subject matter of this study and are expected to respond appropriately to the items on the research instrument. Respondents were also categorised on the basis of job status. Thus, $54.2 \%$, were junior staff, $44.4 \%$ were senior staff, and $1.4 \%$ were management staff; signifying that the study cut across all staff categories with the junior level managers in simple majority. It appears that the study also cut across all departmental units of the organizations.

\subsection{Relationship between Firm's Concern towards Improving Staff Working Conditions and Competitive Advantage}

The question whether company's concern towards improving staff working conditions impacts on its level of competitiveness is analysed and discussed. To that extent, staff working condition otherwise known as staff welfare was operationalised into five constructs: staff morale (SMorale); flexible work hours (WFlex); equitable compensation (Equitcom); work life balance (Worklife); and internal promotion (IntPromo). Table 2 summarises results of linear regression between "staff welfare (SW) and competitive advantage (CA) for the studied organization".

Table 2 revealed that the overall coefficient of correlation and determination $\left(R \& R^{2}\right)$ respectively are 0.547 and 0.299 . The coefficient of regression $(\mathrm{R}=0.547)$ is an indication of strong and positive relationship between predictor variables (SMorale; WFlex; Equitcom; Worklife; \& IntPromo) and dependent variable (CA). The coefficient of determination $\left(\mathrm{R}^{2}=0.299\right)$ implies that only about $29.9 \%$ of the variation in CA can be explained by changes in the totality of concern for staff welfare as a CSR initiative. The remaining $70.1 \%$ cannot be explained which means that the unexplained variation may be related to other variables which are not captured by regression model. However, the overall fit of the regression equation is moderate given an F-statistics of 12.040. At 0.05 level of significance, the overall equation is insignificant at 0.05 probability level since the probability 
Table 1. Respondents’ socio-demographic profile: $\mathrm{N}=142$.

\begin{tabular}{cccc}
\hline Demographic characteristics & Variable & $\mathbf{N}$ & $\mathbf{\%}$ \\
\hline Gender & Male & 77 & 54.2 \\
Age of respondent & Female & 65 & 45.8 \\
& Less than 30 years & 42 & 29.6 \\
Working experience & 30 - 40 years & 82 & 57.7 \\
& 41 - 50 years & 13 & 9.2 \\
Highest qualification & 51 yrs and above & 5 & 3.5 \\
& 1 - 5 years & 72 & 53.3 \\
& 6 - 10 years & 43 & 31.9 \\
& 10 - 15 years & 7 & 5.2 \\
Marital status & 16 yrs and above & 13 & 9.6 \\
& SSCE/WAEC & 3 & 2.1 \\
& OND/NCE & 8 & 5.6 \\
& HND/B.SC/B.A & 107 & 75.4 \\
& M.SC/MBA & 24 & 16.9
\end{tabular}

Table 2. Summary of regression analysis between staff welfare and competitive advantage.

\begin{tabular}{cccccc}
\hline Variable & Beta estimate & Std. error & T statistics & $\mathrm{p}$ & Remark \\
\hline (Constant) & 9.081 & 1.658 & 5.476 & 0.000 & \\
Staff morale (SMorale) & 0.107 & 0.332 & 1.228 & 0.222 & Not significant \\
Flexible work hours (WFlex) & 0.177 & 0.374 & 1.840 & 0.068 & Not significant \\
Equitable compensation (Equitcom) & -0.027 & 0.359 & -0.273 & 0.785 & Not significant \\
Work life balance (Worklife) & 0.425 & 0.276 & 4.855 & 0.000 & Significant \\
Internal promotion (IntPromo) & 0.326 & 0.207 & 6.630 & 0.000 & Significant \\
$\mathrm{R}$ & & & 0.547 & & \\
$\mathrm{R}^{2}$ & & & 0.299 & & \\
Adjusted. $\mathrm{R}^{2}$ & & 0.274 & & \\
Standard error & & 2.90136 & & \\
D-Watson & & & 1.343 & & \\
F-value & & 0.0867 & & \\
Overall p value & & & & & \\
\hline
\end{tabular}

Dependent variable: competitive advantage.

value $(\mathrm{p}=0.867>0.05)$. Thus, in this context, we may construe that a firm's concern towards improving staff working conditions has no significant effect on its competitive advantage. This may imply that staff welfare may not be a good predictor of competitiveness in Nigerian telecoms industry. 


\subsection{Effect of Company's Concern towards the Working Environment on Its Competitive Advantage}

It was also speculated that corporate concern towards the working environment would have no significant effect on competitive advantage. Environmental concern can be demonstrated by implementing workplace safety initiative (Wsafety), reducing operational impacts on climate and air pollution (Climate), reducing workplace hazard (Wharzard), enhancing health of community dwellers (Hcommunity), and sponsoring voluntary community development programmes (Voluntary CDP). Table 3 summarizes results of linear regression between the five dimensions of "environmental development concern (ED) and competitive advantage (CA) for the organization under study.

The result of multiple regression analysis (Table 3) shows that that at 0.01 level, the ANOVA showing overall fit of the regression equation is good given an F-value of 17.990. At 0.01 level of significance, the overall equation is significant since the overall probability value $(\mathrm{p}=0.001>0.05)$. Thus, in this case, it is assumed that a firms' concern towards its operating environment has significant effects on its competitive advantage. This simply suggests that implementing CSR policies that consider the safety and development of environment can be good predictor of market value competitiveness.

Note also that except Hcommunity (Beta $=0.418 ; \mathrm{t}=5.005 ; \mathrm{p}<0.000$ ), all other measures of environmental development used in this studies were positive and significant. In particular, Wsafety $($ Beta $=0.125 ; \mathrm{t}=2.273$; $\mathrm{p}>$ 0.065), made the highest and most significant contribution towards predicting CA. This simply suggests that telecoms firms that consider the safety of their operating environment as part of the social responsibilities are most likely to make significant competitive gains.

\subsection{Corporate Contribution towards Community Wellbeing and Its Effect on Competitive Advantage}

It was predicted that the firm's contribution towards community wellbeing does not enhance its competitive advantage. The Pearson Chi-square was used in this context to analyze the effects of CSR contributions towards community wellbeing on market competitiveness. Results (Table 4) yielded Chi-square calculated $\chi_{\text {cal }}^{2}$ value of 60.143 which is greater than the critical Chi square value $\left(\chi_{\text {tab }}^{2}\right)$ of 21.03 at 0.05 level of significance and 12 degrees of freedom. Thus, a decision is made that firm's contribution towards community wellbeing has positive effect on competitive advantage. This may imply that firms' that contribute towards environmental development and sustainability as part of its social responsibility are bound to impact positively on its market valuesincreased brand awareness and patronage, good corporate image and corporate reputation, higher employee commitment, enhanced job pursuit intention and increased profit etc. As shown on the study, these advantages can be achieved by regularly awarding scholarship and employment to qualified indigenes, provision of recreational and educational facilities to its operating communities, improving socio-economic welfare of the people through development programmes, supporting internal security initiatives and arrangement (e.g., community policing), and peace building.

Table 3. Summary of regression analysis between concern for environmental development and competitive advantage.

\begin{tabular}{|c|c|c|c|c|}
\hline Variable & Beta estimate & Std. error & $\mathrm{T}$ statistics & $\mathrm{p}$ \\
\hline (Constant) & 15.051 & 1.619 & 9.297 & 0.000 \\
\hline Wsafety & 0.418 & 0.221 & 5.005 & 0.000 \\
\hline Wharzard & 0.262 & 0.260 & 2.999 & 0.003 \\
\hline Climate & 0.231 & 0.321 & 2.583 & 0.001 \\
\hline Hcommunity & 0.125 & 0.256 & 2.273 & 0.065 \\
\hline Voluntary CDP & 0.207 & 0.260 & 4.102 & 0.000 \\
\hline
\end{tabular}

$\mathrm{R}=0.513 ; \mathrm{R}^{2}=0.263 ;$ Adjusted $\mathrm{R}^{2}=0.230 ;$ Std. error $=2.987 ;$ F-value $=17.990, \mathrm{p}=0.001$. Dependent variable: competitive advantage . 
Table 4. Effect of CSR contributions towards community wellbeing on market competitiveness.

\begin{tabular}{|c|c|c|c|c|c|c|c|}
\hline $\mathrm{S} / \mathrm{N}$ & Variable & SA & A & $\mathrm{U}$ & $\mathrm{D}$ & SD & Total \\
\hline 1 & $\begin{array}{c}\text { SEQIW = The organisation award scholarship and employment to } \\
\text { qualified indigenes. }\end{array}$ & 51 & 43 & 14 & 19 & 15 & 142 \\
\hline 2 & $\begin{array}{c}\text { RFCY }=\text { The organisation provides recreational facilities to its } \\
\text { operating communities. }\end{array}$ & 63 & 49 & 12 & 11 & 7 & 142 \\
\hline 3 & $\begin{array}{c}\text { SEWS = The company strives to improve socio-economic welfare } \\
\text { of the society. }\end{array}$ & 76 & 38 & 6 & 14 & 8 & 142 \\
\hline \multirow[t]{3}{*}{4} & $\begin{array}{l}\text { ISCPPE = The company supports the community through internal } \\
\text { security, community policing, and peace building. }\end{array}$ & 72 & 43 & 6 & 12 & 9 & 142 \\
\hline & Total & 262 & 173 & 38 & 56 & 39 & 568 \\
\hline & Expected frequencies & 65.5 & 43.3 & 9.5 & 14 & 9.8 & \\
\hline
\end{tabular}

${ }^{*}$ Significant at $\mathrm{p} \leq 0.05$ level $\left(\mathrm{df}=12\right.$; calculated value of $\chi^{2}=60.143$; critical $\left.\chi^{2}=21.03\right)$.

\section{Discussion of Findings}

Understanding how corporate social responsibility can influence market competition in telecoms industry is important to researchers and practitioners in this economic dispensation. Consistent with the above, this study had as its primary aim to examine the influence of corporate responsibility on competitive advantage. To begin with, the study sought to find out the extent in which company’s CSR activities are related to competitive advantage in terms of brand awareness, profitability, reputation, and employee commitment. Results of the multiple regression analysis indicated that a statistically significant relationship exists between corporate social responsibility and competitive advantage $\left(R=0.837, R^{2}=0.701\right.$, F-value $\left.=52.825, \& p<0.01\right)$ of telecoms giant. Thus, the increasing investment in socially responsible practices by firms is capable of enhancing firms' competitive position in its chosen market segment.

The findings of this study indicate that appropriate investment in CSR by a firm through environmental consciousness; active participation and interest on social welfare of communities; sponsoring educational programmes; giving scholarship to deserving students; funding charitable causes; recruiting qualified indigenes and striking a balance between work and family social demands of employees and the like would lead to enhanced positive image of such organization. This finding is consistent with work of [20] who reported a relationship between CSR and financial returns in terms of increase market share, corporate growth and overall profitability of Canadian manufacturing firms. The findings is also in line with [12] study which was based on the assumption that stakeholders will almost always favour a company that acts responsibly and has set up operational policies beneficial to the local community and society at large. [4] found a positive correlation between economic, legal, ethical, and philanthropic concerns and corporate image and reputation, brand awareness, and profitability.

It was also found that the company have demonstrated her environmental concern by implementing workplace safety initiative, reducing operational impact on climate and air pollution, reducing workplace hazard, enhancing health of community dwellers, and sponsoring voluntary community development programmes: $(\mathrm{R}=$ 0.513; $\mathrm{R}^{2}=0.263$; Adjusted $\mathrm{R}^{2}=0.230 ; \mathrm{F}$-value $=17.990, \mathrm{p}=0.001$ ) Thus, implementing CSR policies that consider the safety and development of environment is a pointer to market value competitiveness. Findings also showed that management of the organisation has demonstrated commitment toward its immediate operational community ( $\mathrm{p} \leq 0.05$ level; $\mathrm{df}=12 ; \chi_{\text {cal }}^{2}=60.143$; critical $\chi^{2}=21.03$ ). This was achieved by sponsoring educationally-based programmes; carrying out environmental protection and beautification of most of its operational environment, paying attention to how its activities affect the wellbeing of the people; and providing employment by recruiting qualified indigenes of their communities into the organization; frequently sponsoring cultural activities; and reducing its operational impact on climate change and air pollution by using cleaner fuels.

Findings therefore uphold the fact that CSR actually have positive effect on corporate image of the organization under survey. The result of linear regression analysis shows that CSR makes a contribution of about $95.0 \%$ towards predicting and enhancing positive corporate image. The remaining $5.0 \%$ variance is accounted for because it is the believed that there are other variables outside this study which contribute to corporate image. However, there is a significant relationship between the variables of this study. This particular finding is supported by works of previous researches such as [6] [9] [20] [21].

The current study has serious managerial implication on the premise that when management imbibe and sus- 
tain the philosophy of corporate social responsibility, the image of the company would be positive to customers and the general public. This would stimulate brand support from the masses and other stakeholders; increase revenue from boosted sales; generate positive word of mouth communication and referrals, enhance continuous survival and lead to product and service credibility.

\section{Limitations and Suggestions for Further Research}

Though this study has contributed immensely to existing body of literature, there are still some limitations that may impinge on the generalisation of findings and needs to be brought to the fore. Data for the study were obtained from just one mobile communication firm out of a whole lot that operates in the industry. Perhaps findings would have been different if more locations were considered. In addition, use was made of primary data sourced through the questionnaire alone, other methods, particularly key personal interview (KPI) of respondents outside staff of the organization was not considered. This would perhaps have added additional insight as to how the identified CSR variables impacted on community members as well as the firms' market competitiveness. Further studies should therefore involve more organizations and where possible should be an industry wide study with other methods of data collection employed. Such study should expand its scope to include operating community members as respondents.

In the course of the study, it was found that involvement in CSR activities may be influenced and constrained by certain contingent factors. However, it was beyond the scope of this study to undertake detail investigation of these contingencies. Future studies could examine the divers of corporate organization's involvement in CSR to find out how these can affect their level of competitiveness in the market. It was also found that a firm responsibility to its employee's welfare have moderate but insignificant relationship with achieving competitive advantage. While this finding appears disturbing and controversial, it is a significant aberration from previous research findings. Consequently, a call is hereby made for future research to evaluate the authenticity of this finding to other industries and culture.

\section{Conclusion and Recommendations}

This paper considered the influence of Corporate Social Responsibility (CRS) on competitive advantage in the Nigerian telecommunication industry. The study concluded that corporate social responsibility was having significantly positive influence on competitive advantage and this was equally statistically significant.

The study has demonstrated that a statistically significant relationship exists between corporate social responsibility and corporate competitiveness. This indicates that a firm's involvement in CSR leads to competitive advantage. This can be achieved by being environmentally conscious, awarding scholarship, funding charitable causes, adopting transparent recruitment practices, and striking a balance between work and family roles.

Based on the findings of this study, the following recommendations are made:

- Operations, products and services of the organization should be environmentally friendly. This can be achieved by recycling waste products and other by products that may no longer be useful for sale and public consumption. At the design stage, products should be planned and produced taking environmental degradation into consideration. More so, as part of its social responsibility, awareness activities and campaigns on environmental protection and sustainability should be supported by the firm. The organization should support the government in its drive towards cleaner, greener and sustainable environment.

- There is a need for the studied organization to increase its priority on actions that improve on community wellbeing; this has been shown in the study as having highest degree of positive association with market competitive success.

- Top management should improve its record of environment activities by implementing workplace safety initiatives, enhance health of community dwellers, and reduce operational impact on air pollution and workplace hazard.

- Management should create an enabling business environment where there is respect for socio-cultural values and societal norms, equal opportunities and access for all sexes, fairness and integrity in dealing with employees and customers, transparent and fairness to members of the public and employ a merit basis for awarding contracts.

- Firm must show concern to the staff working conditions by practicing flexible working hours, equitable compensation, ensuring prompt promotion and internal advertisement, and striking a balance between work and 
family demands of employees.

\section{Acknowledgements}

We want to use this opportunity to say big thank you to the anonymous reviewers to this manuscript for a job well done and giving our paper the quality it deserves. Thank you so much Mrs. Keke, Ijeoma Ursula for providing the capacity and resources for carrying out this study. God Bless and take you to greater height in your endeavour.

\section{References}

[1] Holmes, S. and Moir, L. (2007) Developing a Conceptual Framework to Identify Corporate Innovations through Engagement with Non-Profit Stakeholder. Corporate Governance: The International Journal of Business in Society, 7, 414-422. http://dx.doi.org/10.1108/14720700710820498

[2] Porter, M. and Kramer, M. (2006) Strategy and Society. The Link between Competitive Advantage and Corporate Social Responsibility. Harvard Business Review, 78-92.

[3] Berkhout, T. (2005) Corporate Social Responsibility Can Be the Strategic Engine for Long-Term Corporate Profits and Responsible Social Development. Alternatives Journal, 31, 124-138.

[4] Adeyanju, O. (2012) An Assessment of the Impact of Corporate Social Responsibility on Nigerian Society: The Examples of Banking and Communication Industries. Universal Journal of Marketing and Business Research, 1, 17-43.

[5] Heal, G. (2005) Corporate Social Responsibility: An Economic and Financial Framework. The Geneva Papers on Risk and Insurance Issues and Practice, 30, 387-409. http://dx.doi.org/10.1057/palgrave.gpp.2510037

[6] Mahmoud al-Rousan, Keegan, D. and Farid, Q. (2009) The Impact of SWOT Analysis on Achieving a Competitive Advantage: Evidence from Jordanian Banking Industry. International Bulletin of Business Administration, No. 6.

[7] Robbins, S. and Judge, M. (2009) Management and Organization Behavior. 7th Edition, Prentice Hall International, USA.

[8] Dess, G., Lumpkin, T. and Eisner, J. (2009) Strategic Management; Text and Cases. 4th Edition, McGraw-Hill Inc., New York.

[9] George, B., Hugh, C. and Jonathan, L. (1998) Corporate Social Responsibility and Economic Performance in the Top British Companies: Are They Linked? European Business Review, 98, 25-44. http://dx.doi.org/10.1108/09555349810195529

[10] Carroll, A. (1991) The Pyramid of Corporate Social Responsibility: Toward the Moral Management of Organizational Stakeholders. Business Horizons, 34, 39-48. http://dx.doi.org/10.1016/0007-6813(91)90005-G

[11] Frankle, A. and Anderson, J. (2006) Voluntary Social Reporting: An ISO-Beta Portfolio Analysis. Accounting Review, 55, 468-479.

[12] Carrigan, M. (2010) Do Consumers Really Care about Corporate Responsibility? Highlighting the Attitude-Behaviour Gap. Journal of Communication Management, 4, 355-368.

[13] Moon, J. (2004) Government as a Driver of Corporate Social Responsibility. University of Nottingham, International Centre for Corporate Social Responsibility, Research Paper Series, No. 20.

[14] Australian Conservation Foundation (2005) Submission to the Australian Government, Parliamentary Joint Committee on Corporations and Financial Services Inquiry into Corporate Social Responsibility.

[15] Hay, B., Stavins, R. and Vietor, R. (2005) Environmental Protection and the Social Responsibility of Firms. Perspectives from Law, Economics, and Business. Resources for the Future. Routledge, London.

[16] Siegel, D. (2001) Corporate Social Responsibility: A Theory of the Firm Perspective. Academy of Management Review, 2, 117-127.

[17] Besanko, D., Dranove, D. and Shanley, M. (2000) Economics of Strategy. 2nd Edition, John Wiley \& Sons, New York.

[18] Hill, C.J. and Jones, M. (2000) What's in a Name? Reputation Building and Corporate Strategy. Academy of Management Journal, 7, 233-258.

[19] Creswell, B. (2003) Elements of Nonparametric Statistics. John Wiley \& Sons. Inc., New York.

[20] Spencer, B. and Taylor, S. (2003) A within and between Analysis of the Relationship between Corporate Social Responsibility and Financial Performance. Akron Business and Economic Review, 18, 7-18.

[21] Baker, D. (2008) Private Politics, Corporate Social Responsibility and Integrated Strategy. Journal of Economics and Management Strategy, 10, 7-45. 


\section{Appendix}

\section{CSR Competitiveness Scale}

This survey instrument is designed to give you opportunity to evaluate how your company's involvement in socially responsible activities has impacted on its competitive position in the telecoms industry. Kindly indicate the extent of your agreement with the statement below by ticking $[\checkmark]$ one of the spaces provided.

Where: SA = Strongly Agree; A = Agree; U = Undecided, D = Disagree while SD = Strongly Disagree.

\begin{tabular}{|c|c|c|c|c|c|c|}
\hline $\mathbf{S} / \mathbf{N}$ & & SA & A & $\mathbf{U}$ & D & SD \\
\hline RQ1 & Competitiveness by showing concern towards improved staff working conditions. & & & & & \\
\hline 1 & The company motivates its staff and encourages commitment to the job. & & & & & \\
\hline 2 & The company is concerned about having flexible working hours. & & & & & \\
\hline 3 & Compensation and benefits are promptly paid to employees. & & & & & \\
\hline 4 & Achieving high quality work/life balance for employees is important to the organization. & & & & & \\
\hline 5 & Employees are promoted promptly and internal advancement is encouraged. & & & & & \\
\hline RQ2 & Competitiveness by showing concern towards the operating environment. & & & & & \\
\hline 6 & The company takes safety in the work place very serious. & & & & & \\
\hline 7 & $\begin{array}{l}\text { The company has taken measures to reduce its impact on climate change and air pollution by } \\
\text { using clean fuels. }\end{array}$ & & & & & \\
\hline 8 & The firm is committed to reducing work place hazard. & & & & & \\
\hline 9 & The company tries to reduce the impact of its operation on the health of its community members. & & & & & \\
\hline 10 & $\begin{array}{l}\text { The company has demonstrated commitment to voluntary programs, sponsorship of events and } \\
\text { other youth-related activities. }\end{array}$ & & & & & \\
\hline RQ3 & Competitiveness by contributing to community wellbeing. & & & & & \\
\hline 11 & The organisation award scholarship and employment to qualified indigenes. & & & & & \\
\hline 12 & The organisation provides recreational facilities to the communities where it operates. & & & & & \\
\hline 13 & The company has strived to improve socio-economic welfare of the society. & & & & & \\
\hline 14 & $\begin{array}{l}\text { The company is involved in supporting the community through internal security, } \\
\text { community policing, and peace building. }\end{array}$ & & & & & \\
\hline 15 & The company is noted for supporting development initiative made by the community. & & & & & \\
\hline
\end{tabular}

